\title{
Stock market as a game with continuum of players
}

\author{
P. MICHAŁOWSKI \\ pmichalowski@wat.edu.pl \\ Institute of Computer and Information Systems \\ Faculty of Cybernetics, Military University of Technology \\ Kaliskiego Str. 2, 00-908 Warsaw
}

\begin{abstract}
The paper presents specifics and assumptions included in games theory. Author made first attempt to create stock exchange model based on games theory, specific games with continuum of players. The article is the result of efforts to create an adequate mathematic model in order to investigate the specificity of the decisionmaking behavior of so-called individual stock market investors.
\end{abstract}

Keywords: Stock market, behavior models, individual investors, game theory, games with continuum of players.

\section{Introduction}

Stock market has been created during the process of building our civilization. Starting from exchanging one good to another characterized by huge or total lack of formality ending with enormous financial institutions that help in contacts between several investors.

Developing different types of stock markets and at the same time increasing capital flows caused huge interest in those markets in group of corporate investors versus individuals.

It is important to remember that huge contribution of individual investors, as a group does not let ignore them in testing mechanisms that have influence on the stock market. Those mechanisms are under many modeling trials, which may help to better understand stock market and more successfully predict its future form that can lead to maximizing profits.

In my previous work [1] I have described few different approaches to modeling behaviors, especially highlighting stock investors. The next step is trying to build a model of mass investors' behavior based on chosen technique. In [1] I have chosen game theory with continuum of players. Such model is going to be built in this publication.

Game theory is derived from applied mathematics and mathematical economic. It is used in many fields, such as operation research, IT, economy, politics and others with possibilities of separation of conflict situation in several aspects [2], [4], [5].

General game idea is the same as the one we use in everyday life in parlour games. Starting from one point, player continues with sequence of moves by choosing them from set of available or random (e.g. roll the dice) possibilities. Each move is based on the knowledge that player has and uses in an optimal for him way in exact moment. Information that he has in one moment can be complete or not, depending on character of the game. At the end of the game a payoff (e.g. money prize) occurs. Its size depends on process of the game.

Moving to more formal definition, we can say that game is a set of situations in which users (players), according to information they have, make decisions that lead to maximizing the payoff which is influenced by the decisions made by other players as well.

As I mentioned before, the payoff's form is optional (contains not only money), it reflects the preferences of players.

It is worth to say about making decision (strategy - this term is used in game theory). Basically we are used to situation where player decides about his move max few moves ahead or usually in the moment when he has to make that decision. This is confirmed in practice. In many games like chess or bridge the amount of possible moves is so huge that there is no possibility to plan reactions for all of them. In theory we can admit that before starting game, every player decides what to do in each situation. Player's strategy is a full description of all his proceedings (with all information) [4].

Player tries to find a strategy that maximizes his/her payoff - dominant strategy. If for any strategy, we can find a better one, then we call it a dominant strategy [5].

Dominant strategy is the best possible reaction for any strategy used by the oponent. 
Every player uses possible strategies to maximize value of the payoff function, which is described as expected value of the payoff function.

Every limited no cooperative n-people game (this type is described in my work) has at least one system of mixed strategy in equilibrium. Mixed strategies determine probability of choosing a primary strategy for next stage of the game.

Equilibrium stage described by such strategy system is stabile because all of the players do not want to get rid of their strategies, regardless of competitor's action. If one of the player would get rid of his strategy, rational decisions made by other players would lead to equilibrium stage in the game.

In games with non-zero sum (e.g. stock market) equilibrium strategies not always exist. This problem is solved by using Nash equilibrium concept.

There are amounts of each player payoffs, where $a_{s}$ is a first player's payoff, $b_{s}-$ second player's, etc. until $n_{s}$ as $n$ player's payoff with the choice of set of strategies $S$ and $S^{\prime}$ is a set of strategies used by players where strategies are in Nash equilibrium concept:

$$
\begin{gathered}
\vee_{S^{\prime} \neq S} a_{S} \geq a_{S^{\prime}} \text { and } \Lambda_{S^{\prime} \neq S} a_{S}>a_{S^{\prime}} \\
\mathrm{V}_{S^{\prime} \neq S} b_{S} \geq b_{S^{\prime}} \text { and } \Lambda_{S^{\prime} \neq S} b_{S}>b_{S^{\prime}} \\
\quad \cdots \\
\vee_{S^{\prime} \neq S} n_{S} \geq n_{S^{\prime}} \text { and } \Lambda_{S^{\prime} \neq S} n_{S}>n_{S^{\prime}}
\end{gathered}
$$

Nash equilibrium concept is a set of several players' strategies that are the best possible answers to each other. Players' strategies are in Nash equilibrium if they maximize player's payoff in exact choice of other players.

\section{Games with continuum of players}

Attempt to use n-people game theory to economic analysis shows that games with small number of players do not deal with modeling free-market situations. For those matters the most suitable are games that can show "no significance" of individual player which means that his decisions' influence on aggregated values (supply, demand) and their functions (asset price and trading volume) is not relevant.

Buy or sell order made by individual investor practically does not have influence on asset's price and this is clear for the investors. However, taking for consideration large number of players, such decision starts to be influential. Even if that influence is really small, it forms information since it stays in players' awareness and in the same time influences on their decision.

In games with continuum of players, players are represented by points of segment $[0,1]$ with certain probability measure Lebesgue measure in most cases. Another approach are "huge mixed games" where next to continuum of "small" players, there is also a group of "huge" players.

Such games can move from model with finite number of players where huge amount of players can be aggregated for example as clients of brokerage firm to real players. Continuum of users has been introduced for more exact competitive markets' (where individual user does not have any influence on price level but prices are based on users' decisions) research.

Let's think about one situation: does individual investor, while making buy or sale order, consider how it affects the asset's price? The answer is negative. Although, does he make a mistake? Of course not. On the other hand assets' process is determined by the set of such individual decisions. It only shows that choice of games with continuum of players is more accurate.

Using games with continuum of players requires a little bit different approach to few issues. Game with continuum of players is $\sigma$-algebra of $\vartheta$ interval subset $[0,1]$ with actual function $v$ defined on $\vartheta$ under following conditions:

$$
v(\varnothing)=0,
$$

$$
v(A \cup B) \geq v(A)+v(B) \text {, when } A \cap B=\emptyset \text {. (3) }
$$

Elements $\vartheta$ are the coalition and segment's points $[0,1]$ are players. Let's define imputation $\sigma$, as any measure (calculable additive set function), that:

$$
\sigma([0,1])=v([0,1])
$$

Relation of domination will also change. If we want imputation $\sigma$ to dominates over imputation $\tau$, there has to be an inequality $\sigma(S) \leq v(S)$, where $S \in \vartheta$. We cannot say that $\sigma(\mathrm{A}) \geq \tau(\mathrm{A})$, for all $\mathrm{A} \in \mathrm{S}$, because set $S$ is uncountable and $\vartheta$ contains all one-point sets. On the other hand, it is not enough to assume that $\sigma(A) \geq \tau(A)$. In compromise solution inequality $\sigma(\mathrm{A})>\tau(\mathrm{A})$ is applicable for all sets $\mathrm{A} \in \vartheta$ :

$$
\sup _{B \in \vartheta}\{v(A \cup B)-v(B)\}>0,
$$

We do not know enough about stabile sets in games with continuum of players. Guillerme Carmona in his work [21] has proved (based on Nash equilibrium) that equations that are 
suitable for games with finite (countable) number of players can be moved into games with continuum of players assuming certain approximations.

\section{Stock market as a game}

Class of games that are applicable to modeling multiple process of decision making in many time periods are known as dynamic games. They require from player's strategy to define what decision player makes in every moment. We can consider two ways: discreet (set $\{0,1, \ldots, T\})-$ multistage games - or constant (interval $[0, T]$ ) differential games. Mixed situations also happen.

In dynamic games strategies are described as time functions or functions of current state of system, where state in one moment is a result of previous decisions made by players.

Payoff in dynamic game is a sum (integral if time is constant) of discounted at the beginning of game payoffs received in its next stages plus final payoff which depends on state of the system when the game is finished.

To define game we need to define players, information, possible decisions and payoff functions.

Players are all the investors, both: playing (holding shares) and potential (having some amount of money they want to invest).

Players execute orders for buy or sale of assets. Assets include bearer shares.

Players know mechanisms of assets' pricing, commissions table and their wallets' condition. Additionally they have access to information about previous assets price as well as analysis published in the internet, magazines, journals, radio, TV and other media. Individual players use just a part of information because they are not able to fully analyze all the assets by themselves. This is a game with incomplete information and distorted information. Different techniques result in different forms and scope of information (depending on chosen technique, another information matters for player). This is a game where player's information has different forms.

We can assume that each player optimizes his payoff basing on current information, forecasts, actual prices in the future and decision made in the future.

As a model for shaping prices, we will use a GPW (Warsaw Stock Exchange) model.

\section{Simplified model of stock exchange}

Let the game $G$ be determined by set of players, set of strategies and payoffs function.

Players create unit line interval

$\Phi=[0,1]$ with Lebesgue measure $\lambda$. We distinguish $n$ types of players who we can group into separable line intervals $\Phi \mathrm{n}$.

We define $t_{0}$ as a time of starting the game, and by $T$ its over. By $t_{0 n}$ we define time of starting the game by player type $\mathrm{n}$ and by $T_{n}$, end of his game assuming that $t_{0 n} \geq t_{0}$ i $T_{n} \leq T$. Let's assume discrete set of time $T=\left\{t_{0}, \ldots, T\right\}$.

Existing $k+1$ are the types of assets where $k$ can be defined as a sum of $1+m$. Symbol $l$ defines number of companies issuing shares, by $m$ number of companies issuing bonds, and additional asset means cash that stayed in player's wallet. Players' wallets will be described by vectors $k+1$ - dimensional, specified by conditions: having $k$ following shares/bonds and money. Each share contains information about the way of quotation: continuing or single-price.

Set $P$, as a discreet subset of real positive numbers will be defining share prices and because number of shares is 1 , all share prices will be define as $P_{1}$. Set $G$, as a discreet subset of real numbers will be defining bond's value (all bonds' values are in set $G_{m}$ ), and set $O$ defines their percentage (percentage set of all bonds $O_{m}$ ). We expect the share price fluctuation limit per unit of time. Taken from GPW (Warsaw Stock Exchange) can have percentage value of $10 \%$ per share defines by $f$ and 3 percentage points per bond defines by $h$. It means that if the share price in time $\mathrm{t}$ equals $\mathrm{p}$ then in time $t+1$ it has to contain in $[p-f * p, p+f * p]$ Analogously bonds' percentage in time $t+1$ has to contain in $[o-h * o, o+h * o]$.

Shares course in GPW (Warsaw Stock Exchange) is defined of accuracy depending on the course value:

- 1 grosz for course < 50 PLN,

- 5 groszy for course $\geq 50$ PLN and $<100$ PLN,

- 10 groszy for course $\geq 100$ PLN and $<500$ PLN,

- $\quad 50$ groszy for course $\geq 500$ PLN.

Bonds' percentage is defined in accuracy to 0,01 percentage point $(\sigma=0,01)$. Let's assume that bond's value is given in accuracy to 1 grosz $(\sigma=0,01)$. 
To make it easier we can assume that all shares' courses are given in accuracy to 1 grosz $(\sigma=0,01)$ :

$$
\left\{p \in R_{+}\{0\}, \frac{p}{\sigma} \in N\right\},
$$

It is similar with percentage and value of bonds:

$$
\begin{aligned}
& \left\{g \in R_{+}\{0\}, \frac{g}{\sigma} \in N\right\}, \\
& \left\{o \in R_{+}\{0\}, \frac{o}{\sigma} \in N\right\} .
\end{aligned}
$$

Let's assume that player has some amount of money that he can spend during stock operations. It is defined by function $K^{n}(t)$, which quantity is amount of money that can be spend on the stock in time $t$ by type n player.

For every share and bond, investor can make buy or sale orders. Player's decisions are made by sale orders $A s\left(p^{s}, q^{s}\right)$ and buy orders $A b\left(p^{b}, q^{b}\right)$. Parameters $\mathrm{p}$ and $\mathrm{q}$ define price limit (for minimal sale and maximal buy) and number of shares or bonds that are the goal of the order. From every order a constant commission $C$ is charged. Set of all player's decision can be defined as follows:

$$
D=\left\{\begin{array}{c}
\left(A s\left(p^{s}, q^{s}\right), A b\left(p^{b}, q^{b}\right)\right): p^{s}, \\
p^{b} \in P, q^{s}, q^{p} \geq 0
\end{array}\right\},
$$

The set of type $\mathrm{n}$ players' decision is a subset of $D$, defined as $D_{n}$.

We should also consider the restriction of the set $D_{n}$, concerning player's wallet, defined as $x$, when $D_{n}(x)$ contains elements satisfying following conditions:

$$
(1+C) * p^{b} * q^{b} \leq K^{n}(t)
$$

It secures situation in which player's money have to be enough for making a buy order not basing on potential sale order (we do not know if they happen and by which price).

\section{Pricing mechanisms}

According to GPW (Warsaw Stock Exchange) regulations [22] and detailed trading rules [23], financial instruments pricing mechanisms are designated based on following guidelines:

- Maximizing the volume of trading

- Minimizing the difference between the number of financial instruments in sales and purchase orders possible to realize after a specific course

- Minimizing the difference between determined course and reference course.

In such case where the highest price limit of a buy order is lower then the lowest price limit of a sale order or when there are only buy or sale orders or when there are no orders, open course is a first transaction's course made during one session in continuous trading system and closing course is a last transaction's course. If, during one session, there has not been any transaction, opening and closing courses are not presented.

Total supply is described by following formula:

$$
\sum_{i=1}^{k} q_{i}^{s}+\sum_{j=0}^{l} q_{j}^{s}, \text { for } p_{i}^{s} \leq p_{i}(t)
$$

where: $p_{i}^{S}$ is a minimal price for $\mathrm{i}$ assets of s sale order or $j$ bonds of $s$ sale order and $p_{i}(t)$ is a transaction's price in $t$ time.

Demand:

$$
\sum_{i=1}^{k} q_{i}^{p}+\sum_{j=0}^{l} q_{j}^{p}, \text { for } p_{i}^{p} \geq p_{i}(t)
$$

where: $p_{i}^{p}$ is a maximal price for $i$ assets of $s$ buy order or $j$ bonds of $s$ buy order and $p_{i}(t)$ is a transaction's price in $t$ time.

Below is a formula for maximizing trading volume (sum of supply and demand):

$$
\begin{gathered}
\sum_{i=1}^{k} q_{i}^{s}+\sum_{j=0}^{l} q_{j}^{s}+\sum_{\substack{i=1 \\
\leq p_{i}(t)}} q_{i}^{p}+\sum_{\substack{j=0 \\
p}}^{l} q_{j}^{p}, \text { for } p_{i}^{s} \\
\text { MAX }
\end{gathered}
$$

\section{Attempt to define player's strategy}

Set of information available for type $\mathrm{n}$ player is define as $I_{n}$. Players of different types have utility functions that are specified on possible wallet values. Type $n$ player has utility function specified on sets of held information $I$, wallet $P$ and strategy set $D$ :

$$
U_{t}^{n}: I_{n} \times P_{n} \times D_{n} \rightarrow R,
$$

In every time $t$ with held information $I$, wallet $P$ and strategy set $D$ players maximize value of expected utility function which can be described as follows:

$$
U_{t}^{n}\left(I_{n}, P_{n}, D_{n}\right) \rightarrow M A X,
$$

It is also important that form of real expected utility function can be different depending on what form takes appropriate set of information $I$.

Important issue, considering modeling the choice of strategy made by players, is using methods of share values analyzes - the way to get information. There are few methods, below there is a short description of most important ones:

- Technical analysis

- Econometric models

- Fundamental analysis 
- Wallet analysis

- Behavioral analysis

- No model.

Technical analysis is used with short-term investment decision making. It is based on two assumptions. Firstly share price reflects all the factors influencing on it. All that needs to be done is to analyze prices that are results of those factors, not the reasons. Secondly there are several patterns of behavior on the market which can be identified by technical analysis tools and which are repeated in few time periods. Technical analysis is based on models called technical formations which can forecast future share behavior only from charts. Formations have tendency to repeat. There are three types of trends and connected to them types of decisions: growth trend - investor buys, downward trend investor sells, horizontal trend - investors waits with the decision. Second tool used in technical analysis are technical indicators that synthetically characterizes share market.

Another method are econometric models that analyze share courses based on their dependence on different factors, for example macroeconomic variable but also factors that seem no relevant to financial market like weather.

Fundamental analysis on the other hand is based on general attractiveness assessment of chosen shares. This assessment is created in few stages. Macroeconomic analysis lets determine attractiveness of chosen financial market. Sector analysis describes investment attractiveness of companies from chosen sector. Situational analysis concentrates on company's evaluation without, so far, financial data but including such information as: management board quality, strategy, position against the competition, products specificity. Financial analysis concentrates on company's financial condition. After those four stages, there is a time for actual valuation of company's shares. At this stage there are few possible approaches: accounting, liquidation, option, multiplier and income.

Wallet analysis and also CAPM (Capital Asset Pricing Model) - the most popular model is based on searching "effective wallets" that are results of multi-objective optimization from two points of view: maximizing expected wallet value and minimizing standard variance. By using wallet analysis it is possible to count the basic ownerships of cumulative distribution of stock prices. By using CAPM it is possible to count the factors that are marginal contribution of shares in the risk of the wallet. On the basis of these data, you can count the value of expected return.

Behavioral analysis focuses on the market as such, and not on the actions and concentrates on deviations from rationality of investors. There are periods when investors based their actions on rational grounds, suddenly begin to behave differently. Then act like the rest of the investors (herd behavior), mainly for two reasons: the market euphoria and panic.

Investors who do not benefit from any share price model should also be considered. Sometimes, based on the general recommendations of the investors, sometimes they rely on blind luck. Such situations are rare, but, paradoxically, can sometimes provide a reasonable rate of return on investment. An example might be a fictitious stock fund published in the Wall Street Journal, where companies were selected completely randomly, and the result was not significantly different from the result of professional brokers and investment advisors.

As can be seen, depending on the type of user, information is of a different form. For fundamental players it is equal to vector of fundamental values, for wallet players is the average of the last quotation, for technical players it is the vector of information about expected price, for econometric players is a sequence of vectors forecasts.

Each player, while making decision based on given information, calculates a minimal price of selling share or bond and maximum price of buying share or bond. In one word - player chooses strategy.

\section{Summary}

Presented initial game model describing stock market and to be precise - behavior of individual mass investors is a basis for further work.

The next step will be working on a method of choosing appropriate strategy by players of all types, depending on preferred data analyzing methods. This decision may be based on one or more analyzing methods. Additionally, depending on player's characteristic, players can make different decisions (more or less risky). They can also play for a short or long time period and also on "ups" and "downs". Player's decision model (choosing strategy) has to contain the element of influencing other players (not individual) on one player's decisions.

As you can see, there are many decision making criteria and appropriate modeling decision making process should be the next step 
in creating stock market model [3]. This model will be detailed and modified depending on knowledge we have on market mechanisms and financial psychology knowledge.

It seems natural to use multi-criteria methods to present strategy chosen by a player based on the factors that have influence on it [2], [3].

Separate issue is describing a practical way of using mathematical model during next research. Possible direction is to create a right game model (especially games with continuum of players) and to recommend a stage of equilibrium or to use other model [1] to analyze the stock market.

\section{Bibliography}

[1] Michałowski P., "Analyzing the Possibility of Modeling Specificity of an Individual Stock Market Investors' Behavior", Biuletyn Instytutu Systemów Informatycznych, $\mathrm{Nr} 8,53-58$, (2011).

[2] Ameljańczyk A., Multicriteria optimization in control and management problems, Ossolineum, Wrocław, 1984.

[3] Ameljańczyk A., Multiple optimization, WAT,Warszawa,1986.

[4] Ameljańczyk A., Teoria gier i optymalizacja wektorowa, WAT, Warszawa, 1980.

[5] Ameljańczyk A., "A Simplified Method for Determining Equivalent Games and their Solutions", Biuletyn Instytutu Systemów Informatycznych, $\mathrm{Nr} 8,1-8,(2011)$.

[6] Roth A.E., "Subsolutions and Supercove of Cooprative Games", Mathematics of Operations Research, Vol. 1, No. 1, 1976.

[7] Dixit A.K., Nalebuff B.J., Sztuka strategii, MT Biznes Sp. z o.o., Warszawa, 2009.

[8] Kahneman D., Tversky A., "Prospect Theory: An Analysis of Decision under Risk", Econometrica, XLVII, 263-291 (1979).
[9] Luce D., Raiffa H., Gry i decyzje, PWN, 1964.

[10] Schmeidler D., "The nucleolus of a characteristic function game", SIAM Journal of Applied Mathematics, 17, 1969.

[11] Płonka E., Wykłady z teorii gier, WPŚl., Gliwice, 2001.

[12] Owen G., Teoria gier, PWN, Warszawa, 1975.

[13] Rosenmuller J., Game theory. Stochastics, Information, Strategies and Cooperation, Kluwer Academic Publishers, Boston, 2000.

[14] v.Neumann J., Theory of Games and Economic Behavior, Princeton University Press., Princeton, 1944.

[15] JWatson J., Strategia - wprowadzenie do teorii gier, WNT, 2005.

[16] Jajuga K., Jajuga T., Inwestycje, PWN, Warszawa, 2002.

[17] Malawski M., Wieczorek A., Sosnowska H., Teoria gier, PWN, 2004.

[18] Bezalel P., Peter S., Introduction to the Theory of Cooperative Games, Springer-Verlag Gmbh, 2007.

[19] Aumann R., Handbook of Game Theory with economic applications, Vol. 1-3, Elsevier, Amsterdam, 1992; 1994; 2002.

[20] Aumann R., Hart S., Handbook of Game Theory with Economic Applications, Vol. 1-3, Elsevier, 2006.

[21] Carmona G., Nash Equilibria of Games with a Continuum of Players, Universidade Nova de Lisboa, 21 grudnia 2004 r.

[22] Regulamin Giełdy Papierów Wartościowych w Warszawie w brzmieniu przyjętym Uchwałą Nr 1/1110/2006 Rady Giełdy z dnia 4 stycznia 2006 r., tekst ujednolicony według stanu prawnego na dzień 18 lutego 2011 r., http://www.gpw.pl

[23] Szczegółowe zasady obrotu giełdowego, tekst ujednolicony według stanu prawnego na dzień 1 maja 2012 r., http://www.gpw.pl

\section{Giełda jako gra z continuum graczy}

\section{P. MICHAŁOWSKI}

W artykule przedstawiono możliwość wykorzystania teorii gier z continuum graczy w modelowaniu zachowań graczy na giełdzie. Dokonano pierwszej próby opracowania modelu giełdy w oparciu o teorie gier z continuum graczy. Artykuł jest wynikiem prac nad opracowaniem matematycznego modelu pozwalającego badać specyfikę zachowań decyzyjnych tzw. giełdowych inwestorów masowych.

Słowa kluczowe: giełda, modele zachowań, inwestorzy masowi, teoria gier, gry z continuum graczy. 